\title{
The professionals perspective on the causes of project delay in the construction industry
}

\author{
Agyekum-Mensah, G \& Knight, A \\ Author post-print (accepted) deposited by Coventry University's Repository \\ Original citation \& hyperlink: \\ Agyekum-Mensah, G \& Knight, A 2017, 'The professionals perspective on the causes \\ of project delay in the construction industry' Engineering, Construction and \\ Architectural Management, vol 24, no. 5, pp. 828-841 \\ https://dx.doi.org/10.1108/ECAM-03-2016-0085
}

DOI 10.1108/ECAM-03-2016-0085

ISSN 0969-9988

ESSN $1365-232 X$

Publisher: Emerald

Copyright $(\subseteq$ and Moral Rights are retained by the author(s) and/ or other copyright owners. A copy can be downloaded for personal non-commercial research or study, without prior permission or charge. This item cannot be reproduced or quoted extensively from without first obtaining permission in writing from the copyright holder(s). The content must not be changed in any way or sold commercially in any format or medium without the formal permission of the copyright holders.

This document is the author's post-print version, incorporating any revisions agreed during the peer-review process. Some differences between the published version and this version may remain and you are advised to consult the published version if you wish to cite from it. 
The professionals' perspective on the causes of project delay in the construction industry

Author(s):

George Agyekum-Mensah, (Department of Civil Engineering, Architecture and Building, Coventry University, Coventry, UK)

Andrew David Knight, (Department of Construction Management, Nottingham Trent University, Nottingham, UK)

Citation:

George Agyekum-Mensah, Andrew David Knight, (2017) "The professionals' perspective on the causes of project delay in the construction industry", Engineering, Construction and Architectural Management, Vol. 24 Issue: 5, pp.828-841, https://doi.org/10.1108/ECAM-03-2016-0085

\section{Abstract: \\ Purpose}

Construction project delays are described as a universal problem, which has led to many empirical studies. However, most of these studies were based on the rankings by respondents, and they were rarely verified. Therefore, the purpose of this paper is to explore professional perspectives on the causes of delay in the construction industry, where there has been little explicit consideration on this subject in recent decades.

Design/methodology/approach

A critical literature review and a qualitative approach was considered for a deeper and fresh understanding of the causes of delays, rather than recycling the existing themes and the risk of a statistically biased approach. A total of 41 interviews were undertaken which included the London Olympic 2012 project team.

Findings

In all, 32 themes were identified, which were categorised into 15 categories of causes of delay in the construction projects. Almost two-thirds of the main themes are not ranked top 15 causes of delay. These include knowledge and competence shortage, poor commercial decisions, unnecessary health and safety restrictions, poor risk management and poor space and logistics management.

Research limitations/implications

Due to the qualitative nature of the study, the findings might not be considered as representative. Practical implications 
The findings provide consideration of the causes of delay in the construction industry as seen by practitioners, which should provide guidance to enhance performance.

Originality/value

The study contributes to the better understanding of the causes of delays by using qualitative research strategy which is limited in the construction management literature. This study is an empirical investigation into the causes of delay in the twenty-first century and it represents an important edition to the body of knowledge within the subject area.

Acknowledgments:

The authors would like to sincerely thank the case study companies and the interviewees for their valuable contributions and support to this study.

Introduction

The construction industry globally has been faced with the criticisms of delays, which have an extremely negative effect on construction projects. In the UK, the industry has received its equal share of criticisms from governmental organisations, academics and practitioners. Sambasivan and Soon (2007), and Agyekum-Mensah et al. (2012) presented some delays observed in literature and it was established that more than 40 per cent of projects globally experience delays. Colin and Retik (1997) claim 52 per cent of projects in the UK overrun on time, whilst a report from University of Bath conducted by Graves and Rowe (1999) indicated that 70 per cent of the UK public projects exceeded their time estimates. Landmark projects such as Wembley Stadium and the Scottish Parliament in this millennium have attracted a lot of public debate on project delays. Some of which led to claims and litigations between parties. At the beginning of the twenty-first century, a Department of the Environment, Transport and the Regions (2000) report highlighted the problem of time overrun in the UK construction industry. A follow-up UK Governmental study on the overcited Egan (1998) report concluded that the industry's improvement was insignificant (Wolstenholme, 2009). Mair (2014) claimed that 75 per cent of UK council delay construction projects while the UK National Audit Office (2001, p. 4) established that 70 per cent of construction project experience delay A similar report by UK National Audit Office (2010) established that over 80 per cent of PFI in housing projects delay by an average of two years and six months. This, therefore, suggested that delay remains a prevailing challenge within the UK construction industry. In a report, performance of PFI construction, the UK National Audit Office (2009) it was clearly emphasised that "construction performance is central to achieving the Government's delivery of capital projects". The importance of understanding and verifying the causes of delays has become apparent after the global economic recession in 2008.

Despite the studies on the causes of delay in many countries, a search on causes of delay in the UK construction literature found scarcely any. Surprisingly, a search on Association of Researchers in Construction Management, which is one of the largest construction management research depositories in the UK, produced 573 results for "causes of delay, UK" but none of them was directly a study in the UK in recent decades. An early study in the UK on the causes of delays was that of Sullivan and Harris (1986). In this study, the authors examined large construction projects in the UK where 19 causes were identified; of these waiting for information, variation orders and ground problems were ranked highest. However, the construction industry has moved on and there have 
been changes which include the 2008 economic recession. Yet, delays still remain a cornerstone problem in the UK construction industry (Wolstenholme, 2009), thus worth researching.

Most studies on the causes of delay found in literature are based on the rankings by respondents (random participants), and they are rarely verified by practitioners (the people involved). However to understand real life issues in specified industries, it is appropriate to ask the people involved. Therefore, this study closes this gap in knowledge by qualitatively exploring the causes of delay in the UK construction industry in the post-recession era. There are four main parts in this paper, the literature review, which establishes the present state of knowledge; followed by the methods used for the study, the results, analysis and discussion on main causes of delay, and conclusions drawn.

Literature review

What is a delay?

Many researchers have different definitions for "delay"; however, in this study delay is defined simply as "the inability to meet the scheduled time". Delays are classified into two main types, excusable and non-excusable. By and large, excusable delays are those that are understandable by the parties and non-excusable are the opposing type (Colin and Retik, 1997). Trauner (2009) argues that there are two types of excusable delays; which are compensable and non-compensable. Compensable delays are usually where the contractor is reimbursed in time and cost. These are usually client initiated delays but the non-compensable are the opposite. Construction project delays can be attributed to a variety of reasons and could be initiated by any of the stakeholders on projects. Atkinson (1999) claims that construction projects are continuously described as failing. Sweis et al. (2008) insist that despite the advanced technology and project management techniques available to the practitioners, construction projects experience delays.

Causes of delay

Baldwin et al. (1971) is one of the early studies to clearly present the causes of delays in construction in the USA. They identified 17 delay factors where the top five were weather, labour supply, subcontractors, design changes, shop drawings and foundation conditions. This was followed with the study of Arditi et al. (1985) conducted in Turkey and 23 causes of delay were found. Top on their findings were shortage of materials, difficulty in receiving payments from agencies, contractor's difficulties to get loans and credit purchase, and organisational characteristics. Then in the UK, the study of Sullivan and Harris (1986) established 19 causes of delays, with waiting for information, variation orders and ground problems ranked highest. Since then numerous researchers have examined the causes of construction delays in various countries as shown in Tables I and II. Among the studies, Hamzah et al. (2011), Sweis et al. (2008) and Fallahnejad (2013) produced a critical review on the causes of delays observed in literature. Hamzah et al. (2011), and Sambasivan and Soon (2007) concluded their critical review on causes of delay by identifying the main causes; these include, poor planning, poor site management, financial issues, delay of material delivery and management problems. Although Lim and Mohamed (2000) did identify planning (project management) as one of the main problems in construction in Malaysia, they ranked lack of experience, lack of site supervision and lack of appropriate skills in this order as the main problems. Sweiss et al. (2008) believed that these main causes can be grouped into three categories, which are, input factors (concerned with labour, material and equipment), internal environment (contractor, owner and consultants) and exogenous factors (weather and government regulations). Fallahnejad (2013) presented 19 study reviews including his study on causes of delays around the world. 
Although, literature has indicated that delay is a universal issue within construction, empirical study in the UK on the causes of delay in the twenty-first century is sparse (McCord et al., 2015). Sullivan and Harris (1986) is one of the main studies in the UK on the causes of delay where large construction projects were examined. A recent questionnaire survey conducted within the housing sector in the Northern Ireland by McCord et al. (2015) identified deficiencies in site management, ineffective communication strategies and a lack of coordination between key stakeholders involved in the construction process as the key findings.

The questionnaire survey by Fallahnejad (2013, pp. 143-145) concluded that the ten most important causes of delay were "imported materials, unrealistic project duration, client-related materials, land exploration, change order, contractor selection methods, payment to contractor, obtaining permits, suppliers and contractor's cash flow". A similar questionnaire survey conducted by Sambasivan and Soon (2007, p. 526) in Malaysia also concluded with ten causes of delays. These were "contractors improper planning, contractor's poor site management, inadequate contractor's experience, inadequate client's finance and payments for the work, problems with subcontractors, shortage of materials, labour supply, equipment availability and failure, lack of communication between parties, and mistake during construction stage". From these studies, it can be inferred that inappropriate planning and poor project management are significant causes of delay. Another study conducted in Malaysia by Memon (2014) identified slightly different top factors from Sambasivan and Soon (2007). Memon (2014) established the following as the top factors: frequent design changes, change in the scope of the project, financial difficulties of owner, delays in decisions making and unforeseen ground condition. The difference between the findings of these two studies could arguably be the years the research was conducted. The study of Sambasivan and Soon was conducted in 2007, which was just before the global recession and that of Memon was in 2014 after the recession.

Sepasgozar et al. (2015) argues that a key cause of delay is the continuous use of outdated construction technologies. Hamzah et al. (2011) concluded that the reduction of delay is not only limited to the consideration of technical factors, but also to issues of project management. Agyekum-Mensah et al. (2012) and Hubbard (1990), among other researchers, claim that many problems within construction are due to lack of effective project management. Equally, Sweis et al. (2008) ascertain that there are major failings in the traditional approaches to project delivery. Despite all the advances in project management theory and practice, Hartman and Ashrafi (2004) claimed construction project success is still below 40 per cent. Shehu et al. (2014) claim that delay in Malaysia is mainly associated with financial problems by the contractor.

Sambasivan and Soon (2007) and Fallahnejad (2013) reviewed on causes of delays and concluded that improper planning is the most likely cause of delay, followed by poor site management. According to Sweis et al. (2008), responses from both consultants and clients ranked poor planning as the main cause of delay. According to Colin and Retik (1997), construction schedule, regardless of type plays a vital part in managing the construction process. They claim that the schedule is vital in identifying, preparing, analysing or refuting delay claims because they provide a specific medium for comparing and measuring time and meaning. Furthermore, they claim that the construction schedule is significant when it is applied to measure delays. Similarly study in Libya, Tumi et al. (2009) identified improper planning, lack of effective communication, design errors, shortage of 
supply, slow decision making and financial issues ranked highest. A review conducted by Memon (2014) identified 30 causes of delay. There are different causes of delay in literature which have not been verified.

Therefore, in this study a critical review of 24 studies was conducted on the causes of delay and 30 common causes were identified. Table I provides the top 15 established in the existing literature as the causes of delay.

Research methods used in studies on causes of delay

Most researchers use surveys as the research method to investigate the causes of delay; for example, Mansfield et al. (1994), and Sullivan and Harris (1986) presented the causes of delays in construction in Nigeria and the UK, respectively. Table II presents studies observed in literature in the twenty-first century on the causes of delay from different countries, which also shows that the UK has not been covered. It is acknowledged that some books authors such as Trauner (2009) have asserted their views on causes of delays, but Table II focusses on empirical studies and/or peer reviewed publications.

Table II shows that in the studies identified for causes of delays, survey is the dominant approach used. Perhaps, this is because of the dominance of quantitative (survey) research in construction management as a field of study (Knight and Ruddock, 2008). Using surveys in this case, only allows the existing factors in literature to be revolved, thus, there is no new understanding or verification of the problem. Dainty (2008) argues that this has encouraged a convention of applying a "natural science" strategy to understand social phenomena. He further established that fewer than 9 per cent of papers published in Construction Management and Economics Journal (up to vol. 24) used the qualitative method exclusively. However, it is imperative that to understand the "real-world" problem of why something occurs like, the causes of delay, it is important to ask those involved in the project (Robson, 2011; Seymour et al., 1998). This is consistent with this study, which is to explore the causes of delay from the participants' experience.

Research design

In order to further explore the causes of delays, within a contemporary period of economic austerity, and more specifically to understand professional perspective within this context, a qualitative study was undertaken (Farrell, 2011). A qualitative approach was adopted for this study for gathering rich data from which ideas are induced and the experience of the participants is vital. This approach enabled the exploration of key themes, understanding and attitudes of those who work within a project environment on a daily basis. Project cases were purposively selected within which interviews were undertaken as the main data collection method. Proverbs and Gameson (2008) describe case study research as extremely applicable to a project driven industry. Multiple case studies were used to explore the causes of delay, which gave a deeper understanding of the subject under investigation (Bryman and Bell, 2011). There were closing interviews conducted with professionals subsequent to the case studies. These interviews were intended to explore contrasting and comparative understanding of the research subject and also to give a general perspective. Generally, critics describe this approach as methodologically weak; thus, the authors being aware of this weakness put mitigation measures in place (predominantly using the recommendations of these studies: Yin, 2009; Easterby-Smith et al., 2012; Bryman and Bell, 2011; Strauss and Corbin, 1998; Knight and Ruddock, 2008; Farrell et al., 2016). These include robust research design, where the data collection spans from July 2011 to April 2013. Although, majority of the studies on causes of delays a 
adopt quantitative strategy which is contrary to this study's strategy, few studies such as Lim and Mohamed (2000) used a qualitative approached to gather rich data on causes of delays in Malaysia, where they conducted 40 interviews.

In this study a total of 41 interviews were undertaken. This comprised 26 interviews conducted within the four project case studies and an additional 15 with the general purposively sampled participants (experienced practitioners). The case studies were selected from predominately UK construction companies. Two of the case studies were notable main contractors executing landmark projects in the UK, whilst one each was within subcontractor and engineering settings. These cases were chosen as being representative of all sectors of the UK construction industry. Fellows and Liu (2015) agree that case sampling is a vital part in case study research; he however asserts that balance and variety are equally important to strengthen findings. Three of the cases were based in central England, and the other one was in East Lothian, Scotland. The case studies focus on main contractors' views, thus one may argue it is limited. Therefore, additional interviews were conducted with most of the main stakeholders in construction projects. These included developers, consultants, clients and contractors. The closing semi-structured interviews were conducted with senior members in reputable organisations and landmark project members, which included the London 2012 and Wembley Stadium. The participants were purposively selected, where criteria include, participant should:

- senior manager in reputable organisation and/or on a project;

- have over 15 years industrial experience; and

- be academically and professionally qualified.

The interviews were audio recorded and transcribed verbatim. Content analysis was adopted and the analysis was facilitated by the use of Nvivo software. The analysis is concerned with interpreting the interviews rather than reducing the data to statistical counts. This is to retain the richness of the interviews conducted with highly experience participants. The participants were anonymously coded for unreserved analysis. The analyses of the case studies were cross-discussed separately from the industrial interviews. The empirical themes grouped into larger categories, which were later crossed discussed with the industrial interviews to identify the similarities as well as differences. In total, 32 themes were identified which were grouped into 15 main categories.

Analysis and discussion

The case studies interviews

The data collected from the four case study interviews were cross-discussed to establish the similarities as well as differences. Analysis of the case study interviews suggested 30 empirical common themes as causes of delays which were grouped into 11 main categories (see Table III) against the 14 attributes and eight themes gathered from the closing general practitioners interview (see Table IV). In total, 15 main themes were identified in this study. Individuals react to delays in different ways. For example, the project manager whose responsibility is to deliver the project on schedule is suggested to be panicking, whilst the cost manager is interested in the "blame game". This is clearly expressed by the cost manager who is a chartered surveyor with many years of experience: 
[...] again, looking at our interest so that we can pass on blame if it is a better term. If a client is causing [the delay], we believe the client should recompense us for that. That might be an extension of time, it might be acceleration or it might be anything.

This participant further admits that the main problem that causes delay is late procurement of subcontractors. However, he was quick to add that if there are weekly meetings these would, perhaps, be eliminated. Therefore, he explains:

I have to admit that as a surveyor I don't panic as the project manager panics. I accept as a surveyor there will be areas that we can affect. If we are late in procuring subcontractors that will have significant effect [on the project]. The weekly progress meetings are essential because that allows the project manager to say I need somebody in the next two weeks to do something.

This problem is shared with the designers of the case studies, who suggest that they did not know when some drawings were needed on site. This problem of "blame game" led to participants suggesting that liquidated damages should be levied against designers as with subcontractors. The project manager said:

On this job we had the design and procurement programme and it is probably six months behind. It has never been tracked therefore there was no need to put effort in to do it in the first place. I think we have in the back of our minds knowing what we need to concentrate on and doing it that way.

The project manager in case study four says:

I think another problem we have in reality is that we sign up to programme that is too tight so we have very less capacity in our programme; therefore, any matter becomes delay rather than becomes an issue they get resolved and of course the end results is delay. I think we are too polite, too soft or whatever with a client to say NO we need more time.

Alternatively, "poor commercial decisions" and "poor space and logistics management" were suggested to be causes of delays. The most intriguing problem established in both is the issue of health and safety. Some participants, especially, from the subcontractors deemed health and safety as a problem to project management but it was interesting to note that this view is also shared by a site manager, with a master's level education and significant experience. This participant explained and later cited examples: 
[...] unnecessary Health and safety, even though it is good for the people, it can also cause delay to the project in such a way that, even though there are no short cut to achieve our goals there are some things that could have been done in an easier way but following the health and safety regs it is assumed to be safe but it turns to delay the project

(Case study two, Site Engineer).

The Project lead in case study two disagrees and said "[...] lack of maintenance of that environment out there so guys are not working efficiently". This participant believes maintaining a clean environment on site allows subcontractors to work more efficiently. However, they do not refute the site managers claim that unnecessary health and safety causes delays. In as much as the senior project manager stressed that health and safety is a good thing for the project, he makes an additional point that "[...] Scaffolding takes time. Scaffolding is not normally built into a programme. On this job it takes a long time to put scaffolding up".

The closing interviews - general practitioners

Delays in construction as previously discussed could be initiated by any of the stakeholders and a typical problem. The senior project manager described delays as a common problem in construction; however, the effect of delays on project participants varies especially clients and contractors. This participant argues that:

[...] project slipping over its planned schedule is considered as a common problem in construction projects. To the owner, delay means loss of revenue through lack of production of facilities and rent-able space or a dependence on present facilities. In some cases, to the contractor, delay means higher overhead costs because of longer work period, higher material costs through inflation, and due to labour cost increases.

The Director believes "[...] we sometimes talk about 'delays' which are not delays per se but poor programming at the start of the project for not assessing the productivities realistically etc.". The senior project manager believes the "[...] original contract duration [given by project owner] being too short". The project director emphasises this by asserting "I have already said that insufficient planning is the main cause [...]". Whilst, the planning manager asserts, "[...] causes of delays could be scope creep, changes, lack of clarity or unclear brief".

However, programme director believes delay is caused by a "[...] failure to undertake a comprehensive assessment of the ground conditions". "It could be insufficient detailing in design or specification; it could be technical specification" was the response of the contractor's managing director. The project engineer from a consultancy background advise that although despite this lack of assessment there are "[...] not enough contingency allowed to deal with delays easily".

The managing director believes delays are caused by inappropriate resources allocation to projects, which is arguably due to financial problem or shortage of resources. This participant asserts: 
[...] very often from the contractors' point of view, the contractors have more than one project going on so it could be internal difficulties having to allocate the same resources to different projects.

Some respondents suggest that the design changes could be due to lack of investigations such as groundwork. The senior project engineer, planning manager and programme director all agree that unknown ground conditions or poor site investigation can cause delays, which is consistent to literature although ranked 15 on the top causes of delay. However, the programme director believes it is a "[...] failure to undertake a comprehensive assessment of the ground conditions". "It could be insufficient detailing in design or specification; it could be technical specification" was the response of managing director. The former stresses on lack of comprehensive assessment conducted at the preconstruction stage while the latter adds from a design perspective. These themes are ranked 5 and 7, respectively, in Table I. The project engineer from a consultancy background advise that despite this lack of assessment detailed site investigations there are "[...] not enough contingency allowed to deal with delays easily".

The project engineer believes that there is not enough allowance of buffer in the programme to cater for some unforeseen delays. Other participants' suggest that lack of experience is among the causes of delays to construction projects. This was clearly stated by the senior project manager as he stressed on the "[...] inadequate experience of consultants, this could apply to contractor depending on the type of contract or procurement". Lack of experience of the individuals or team is not emphasised enough literature as it is not in the top 15 causes of delay as presented in Table I; however, few study such as Lim and Mohamed (2004) ranked within the top ten causes of delay. In addition, the project engineer stated:

"well, the most common problem is the time overrun. In my experience this begins from the start of the project, when I say the start of the project, I mean on site, the project start on site with insufficient information and with decisions yet to be taken so it starts with a built in delay and the delay keep [getting] carried over to the next person and to the next person to the next person and finally the delays keep accumulating". This participant asserts on information flow and delay in decision making.

In the analysis of the closing practitioners' interviews, 14 attributes were identified as the common causes of delay. These attributes were grouped into eight themes. These themes are consistent across a collection of studies but not in a single study. Table IV presents the results of general practitioners perspective on the causes of delay.

The synthesis - interviews

The study established 32 causes of delays; however, insufficient or poor planning and management problems were prevalent. This supplants the waiting for information, variation order, and ground 
problems identified 30 years ago by Sullivan and Harris (1986) in the UK. Again, McCord et al. (2015) identified deficiencies in site management, ineffective communication strategies and a lack of coordination between key stakeholders. In a broader view, the findings of this study are an extension to literature as it establishes "the real world" causes of delay rather than the revolving themes gathered in literature. For example, it was established that poor commercial decisions, and health and safety are claimed to be major causes of delays to construction projects. In addition, practitioners suggest underestimating the complexity of projects equally causes delays. These themes, including unclear initial project objectives and scope creep, are sparsely discussed in construction management literature as causes of delays this millennium. It was noted that scope creep was a problem despite the granting of an extension of time, the public, and most researchers, are only interested in the initial proposed completion date. Thus any overrun to the original stipulated completion date is classified as a delay. Surprisingly poor workmanship and lack of materials which has been discussed in most studies from developing countries, is not raised by participants of this study, rather the emphasis was on management experiences and competences. Other causes of delay such as weather and slowness in approval which are ranked among the top were not suggested by participants in this study.

Another significant finding that has not been given much attention in previous causes of delay literature is unnecessary health and safety requirements, and the issue of experience, knowledge and competence of the individual and the team. Practitioners assert that information flow is equally a major cause of delay. The findings of the case studies and the closing general practitioners interviews complement each other, which is an indicative of the industrial perspective of causes of delay in the UK construction industry. The main themes presented in Table $V$ shows the 15 main categorises of causes of delay. These themes were compared to the top 15 ranked in existing literature as presented in Table I. It was found that almost two-thirds of the themes are not among not cited in the top 15 in literature. These findings could be interpreted in two folds. First, the causes of delays could be specific to a country and/or era but not transferable from one country/region or era to another. Second, it could be argued that the generic lists of causes of delays in literature are not verified, thus, there are no new themes found.

\section{Conclusions}

The authors explored and verified the causes of delay from professionals' perspective in the post 2010 s era in the construction industry as project delays remain one of the biggest challenges. The dominance of quantitative strategy in examining causes of delay does not allow deeper or fresh insight, is not suitable to understand "real life". It is argued that operational problems such as causes of delay could be specific to a country and/or era. It is therefore important that the practitioners' experiences were explored rather than arguably recycling other attributes from existing studies, from different countries, with the potential for statistically biased analysis. The study contributes to the better understanding of the causes of delays by using qualitative research strategy which is limited in the construction management literature.

Although two separate approaches (case study interviews and general interviews) were undertaken, the results complement each other. These represent the common causes of delay in the construction industry. In all, 32 empirical attributes were identified, which were grouped into 15 main themes. There were obviously themes that were consistent with existing quantitative studies 
even from different countries, thus verified. Certain themes such as insufficient planning, poor project management, unclear initial project objectives, communication and inappropriate resource management are consistent with other studies and could be described as universal problems. However, themes including unnecessary health and safety requirements, scope creep, soft management (communication, experience, knowledge and competence), and poor commercial decisions are sparsely discussed in literature.

These findings of the study immensely benefit both academics and practitioners as the main causes of construction delay in the 2010s (post-recession). This enables practitioners to mitigate construction delays to enhance performance and also guide future research for academics. This study is an empirical investigation into the causes of delay in the twenty-first century and it represents an important edition to the body of knowledge within the subject area.

\section{Item Common causes of delay}

1 Inadequate planning

2 Finance and payment

3 Slow in Approving

4 Variation

5 Ground condition

6 Labour supply, and subcontractors

7 Design changes

8 Material shortage

9 Manufactured and imported items

10 Site Management

11 Weather

12 Fluctuation

13 Construction mistake

14 Contractors experience

15 Contingency or unforeseen

\section{Raking based on occurrences}

1

2

3

3

4

5

5

5

5

5

6

6

6

6

6

Table I Top 15 causes of delay observed in construction literature

\section{Author(s)}

Al-Momani (2000)

Lim and Mohamed (2000)

Stumpf (2000)

Odeh and Battaineh (2002)

Frimpong et al. (2003)

Long et al. (2004)

Assaf and Al-Hejji (2006)

$\begin{array}{ll}\text { Country of study } & \text { Method used } \\ \text { Jordan } & \text { Survey } \\ \text { Malaysia } & \text { Case study (interviews) } \\ \text { General } & \text { Literature review } \\ \text { Jordan } & \text { Survey } \\ \text { Ghana } & \text { Survey } \\ \text { Vietnam } & \text { Questionnaire } \\ \text { Saudi Arabia } & \text { Survey }\end{array}$




$\begin{array}{lll}\text { Author(s) } & \text { Country of study } & \text { Method used } \\ \text { Faridi and El-Sayegh (2006) } & \text { UAE } & \text { Survey } \\ \text { Lo } \text { et al. (2006) } & \text { Hong Kong } & \text { Survey } \\ \text { Sambasivan and Soon (2007) } & \text { Malaysia } & \text { Survey } \\ \text { Abd El-Razek et al. (2008) } & \text { Egypt } & \text { Survey (piloted semi-structured) } \\ \text { Le-Hoai } \text { et al. (2008) } & \text { Vietnam } & \text { Survey } \\ \text { Sweiss et al. (2008) } & \text { Jordan, Middle East } & \text { Survey } \\ \text { Toor and Ogunlana (2008) } & \text { Thailand } & \text { Case study (questionnaire and interviews) } \\ \text { Al-Kharashi and Skitmore (2009) } & \text { Saudi Arabia } & \text { Survey } \\ \text { Enshassi } \text { et al. (2009) } & \text { Gaza Strip } & \text { Survey } \\ \text { Han et al. (2009) } & \text { Korea } & \text { Survey } \\ \text { Tumi } \text { et al. (2009) } & \text { Libya } & \text { Survey } \\ \text { Fugar and Agyekwah-Baah (2010) } & \text { Ghana } & \text { Survey } \\ \text { Hamzah et al. (2011) } & \text { General } & \text { Literature review } \\ \text { Mahamid } \text { et al. (2012) } & \text { West Bank, Palestine Survey } \\ \text { Doloi } \text { et al. (2012) } & \text { India } & \text { Questionnaire } \\ \text { Fallahnejad (2013) } & \text { Iran } & \text { Survey } \\ \text { Memon (2014) } & \text { Malaysia } & \text { Survey } \\ \text { Shehu et al. (2014) } & \text { Malaysia } & \text { Survey } \\ \text { McCord et al. (2015) } & \text { Northern Ireland } & \text { Survey } \\ & & \end{array}$

Table II Studies on causes of delay in construction in twenty-first century observed in literature

\section{Attributes}

Game playing for more money

Underestimating the complexity of the project

Professional unassertive

Insufficient design details

Buildability

Insufficient Planning

Addition of items from the planning

Tight programme

Missing activities during planning

Lack of contingency in duration

Lack of management of the tasks interface

Poor management of labour logistic problems

Variations or changes

Scope creep

Unclear project requirements

\section{Themes}

Poor commercial decisions

Design problems

Insufficient project planning

Poor monitoring and control

Scope creep and unclear project

Requirements 


\section{Attributes}

Financial problems

Cost cutting (less resources, smaller site office and less site management)

Improper risks transfer

Improper risk mitigation

Unexpected problem (inc. weather, winds, asbestos and ground problems)

Unexpected problems are encountered (e.g.

discovering services when excavating)

Inexperience and incompetence

Lack of knowledge

Knowledge of alternative construction

methodologies

The quality of the individuals

Health and safety

Late procurement of materials

Lack of resources

Lack of space

Logistic problems

\section{Themes}

Financial problems

Inappropriate risks transfer and mitigation, and unforeseen circumstance

Knowledge, experience and competence

Poor resource management

Poor space and logistic management

Table III The causes of delays - case study participants' perspective

\section{Attributes}

Insufficient project planning

Unrealistic deadlines and deliverables

Poor information flow

Improper communication

Poor management

Inappropriate coordination of team members

Poor performance

Poor risk management

Resource problems

Payment and contractor finance problems

Unclear project objectives/scope

Scope creep

Lack of detail design and design changes

Unforeseen circumstances

Lack of experience and incompetence

\section{Main themes}

Insufficient planning

Poor information flow and communication

Ineffective project management

Financial problems

Unclear project objectives/scope

Scope creep

Design problems

Unforeseen circumstances

Lack of experience and incompetence 
Table IV Causes of delays - the results from the general practitioners perspective

\section{Main categorises}

Insufficient planning

Poor information flow and communication

Poor commercial decisions

Ineffective project management

Poor monitoring and control

Financial problems

Unclear project objectives/scope

Design problems

Unforeseen circumstances

Scope creep

Inappropriate risks transfer and mitigation

Lack of knowledge, experience and competence

Health and safety restrictions

Poor resource management

Poor space and logistics management

Poor application of construction methods

\section{The top 15 established in literature}

$\mathrm{Y}$

$\mathrm{N}$

$\mathrm{N}$

Y

Y

Y

$\mathrm{N}$

Y

Y

$\mathrm{N}$

$\mathrm{N}$

Y

$\mathrm{N}$

$\mathrm{N}$

$\mathrm{N}$

$\mathrm{N}$

Table V The main categorises - practitioners perspective

References

1. Abd El-Razek, M.E., Bassioni, H.A. and Mobarak, A.M. (2008), "Causes of delay in building construction project in Egypt", Journal of Construction Engineering and Management, Vol. 134 No. 11 , pp. 831-841.

2. Agyekum-Mensah, G., Knight, A. and Pasquire, C. (2012), "Adaption of structured analysis design techniques methodology for construction project planning", in Smith, S.D. (Ed.), Procs. 28th Annual ARCOM Conference, ARCOM, Edinburgh, pp. 1055-1065.

3. Al - Kharashi, A. and Skitmore, M. (2009), "Causes of delays in Saudi Arabian public sector construction projects” , Construction Management and Economics, Vol. 27 No. 1, pp. 3-23.

4. Al-Momani, A.H. (2000), "Construction delay: a quantitative analysis", International Journal of Project Management, Vol. 18 No. 1, pp. 51-59.

5. Arditi, D., Akan, G.T. and Gurdamar, S. (1985), "Reasons for delays in public projects in Turkey", Construction Management and Economics, Vol. 3 No. 2, pp. 171-181.

6. Assaf, S.A. and Al-Hejji, S. (2006), "Causes of delay in large construction projects", International Journal of Project Management, Vol. 24 No. 4, pp. 349-357.

7. Atkinson, R. (1999), "Project Management: cost, time and quality, two best guesses and a phenomenon, it's [its] time to accept other success criteria", International Journal of Project Management, Vol. 17 No. 6, pp. 337-342. 
8. Baldwin, J.R., Manthei, J.M., Rothbart, H. and Harris, R.B. (1971), "Causes of delay in the construction industry", Journal of the Construction Engineering Division, Vol. 97 No. 2, pp. 177-187.

9. Bryman, A. and Bell, E. (2011), Business Research Methods, 3rd ed., Oxford University Press.

10. Colin, J. and Retik, A. (1997), "The applicability of project management software and advanced IT techniques in construction delays mitigation", International Journal of Project Management, Vol. 15 No. 2, pp. 107-120.

11. Dainty, A. (2008), "Methodological pluralism in construction management research", in Knight, A. and Ruddock, L. (Eds), Advance Research Method in Built Environment, WileyBlackwell, Oxford, pp. 1-12.

12. Department of the Environment, Transport and the Regions (2000), Performance indicators show improvement, Construction Monitor, available at:

www.gov.uk/government/uploads/system/uploads/attachment_data/file/16323/file16441. pdf (accessed 29 October 2013).

13. Doloi, H., Sawhney, A., Iyer, K.C. and Rentala, S. (2012), "Analysing factors affecting delays in Indian construction projects", International Journal of Project Management, Vol. 30 No. 4, pp. 479-489.

14. Easterby-Smith, M., Thorpe, R. and Jackson, P. (2012), Management Research, 4th ed., SAGE Publication, London.

15. Egan, J. (1998), Rethinking Construction, the report of the Construction Task Force, Department of Environment, Transport and Regions, London.

16. Enshassi, A., Al-Najjar, J. and Kumaraswamy, M. (2009), "Delays and cost overruns in the construction projects in the Gaza Strip", Journal of Financial Management of Property and Construction, Vol. 14 No. 2, pp. 126-151.

17. Fallahnejad, M.H. (2013), "Delay causes in Iran gas pipeline projects", International Journal of Project Management, Vol. 136, pp. 136-146.

18. Faridi, A.S. and El - Sayegh, S.M. (2006), "Significant factors causing delay in the UAE construction industry” , Construction Management and Economics, Vol. 24 No. 11, pp. 1167-1176.

19. Farrell, P. (2011), Writing a Built Environment Dissertation, Wiley-Blackwell, West Sussex.

20. Farrell, P., Sherratt, F. and Richardson, A. (2016), Writing a Built Environment Dissertation and Projects, 2nd ed., Wiley-Blackwell, West Sussex.

21. Fellows, R. and Liu, A. (2015), Research Methods for Construction, 4th ed., Wiley-Blackwell, West Sussex.

22. Frimpong, Y., Oluwoye, J. and Crawford, L. (2003), "Causes of delays and cost overruns in construction of groundwater projects in developing countries: Ghana as a case study", International Journal of Project Management, Vol. 2 No. 5, pp. 321-326.

23. Fugar, F.D.K. and Agyekwah-Baah, A.B. (2010), "Delays in building construction project in Ghana", Australasian Journal of Construction Economics and Building, Vol. 10 Nos 1-2, pp. 103-116.

24. Graves, A. and Rowe, D. (1999), "Benchmarking the government client. Construction the best government client", HM Treasury Report, London.

25. Hamzah, N., Khoiry, M.A., Arshad, I., Tawil, N.M. and Ani, A.C. (2011), "Cause of construction delay - theoretical Framework", Procedia Engineering, Vol. 20, pp. 490-495. 
26. Han, S.H., Yun, S., Kim, H., Kwak, Y.H., Park, H.K. and Lee, S.H. (2009), "Analysing schedule delay of mega project: lesson learned from Korea Train Express", IEEE Transactions on Engineering Management, Vol. 56 No. 2, pp. 243-425.

27. Hartman, F. and Ashrafi, R. (2004), "Development of the SMARTTM project planning framework", International Journal of Project Management, Vol. 22 No. 6, pp. 499-510.

28. Hubbard, D.G. (1990), "Successful utility project management from lessons learned", Project Management Journal, Vol. 21 No. 3, pp. 19-23.

29. Knight, A. and Ruddock, L. (2008), Advance Research Method in Built Environment, WileyBlackwell, Oxford.

30. Le-Hoai, L., Dai Lee, Y. and Lee, J.Y. (2008), "Delay and cost overruns in Vietnam large construction projects: a comparison with other selected countries", KSCE Journal of Civil Engineering, Vol. 12 No. 6, pp. 367-377.

31. Lim, C.S. and Mohamed, M.Z. (2000), "An exploratory study into recurring construction problems", International Journal of Project Management, Vol. 18 No. 4, pp. 267-273.

32. Lo, T.Y., Fung, I.W. and Tung, K.C. (2006), "Construction delays in Hong Kong civil engineering projects", Journal of Construction Engineering and Management, Vol. 132 No. 1, pp. 636649.

33. Long, N.D., Ogunlana, S., Quang, T. and Lam, K.C. (2004), "Large construction projects in developing countries: a case study from Vietnam", International Journal of Project Management, Vol. 22 No. 7, pp. 553-561.

34. McCord, J., McCord, M., Davis, P.T., Haran, M. and Rodgers, W.J. (2015), "Understanding delays in housing construction: evidence from Northern Ireland", Journal of Financial Management of Property and Construction, Vol. 20 No. 3, pp. 286-319.

35. Mahamid, I., Bruland, A. and Dmaidi, N. (2012), "Causes of delay in road construction project", Journal of Management in Engineering, Vol. 28 No. 3, pp. 300-310.

36. Mair, L. (2014), Almost $75 \%$ of council cancel or delay construction projects, The Architect Journal, EMAP Publishing Limited, London, available at:

www.architectsjournal.co.uk/news/almost-75-of-councils-cancel-or-delay-constructionprojects/8674168.article (accessed 27 May 2016).

37. Mansfield, N.R., Ugwu, O. and Doran, T. (1994), "Causes of delays and cost overruns in Nigerian construction projects", International Journal of Project Management, Vol. 12 No. 4, pp. 254-260.

38. Memon, A.H. (2014), "Contractor perspective on time overruns factors in Malaysian construction projects", International Journal of Science, Environment and Technology, Vol. 3 No. 3, pp. 1184-1192.

39. Odeh, A.M. and Battaineh, H.T. (2002), "Causes of construction delay: traditional contracts", International Journal of Project Management, Vol. 20, pp. 67-73.

40. Proverbs, D. and Gameson, R. (2008), "Case study research", in Knight, A. and Ruddock, L. (Eds), Advance Research Method in Built Environment, Wiley- Blackwell, Oxford, pp. 99-110.

41. Robson, C. (2011), Real World Research: A Resource for Users of Social Research Methods in Applied Settings, 3rd ed., John Wiley \& Sons Ltd, West Sussex.

42. Sambasivan, M. and Soon, Y.W. (2007), "Causes and effects of delays in Malaysian construction industry", International Journal of Project Management, Vol. 25 No. 5, pp. 517526.

43. Sepasgozar, S.M.E., Razkenari, M.A. and Barati, K. (2015), "The importance of new technology for delay mitigation in construction projects", American Journal of Civil Engineering and Architecture, Vol. 3 No. 1, pp. 15-20. 
44. Seymour, D., Crook, D. and Rooke, J. (1998), "The role of theory in construction management: reply to Runeson", Construction Management and Economics, Vol. 16 No. 1 , pp. 109-112.

45. Shehu, Z., Endut, I.R. and Akintoye, A. (2014), "Factors contributing to project time and hence cost overrun in the Malaysian construction industry", Journal of Financial Management of Property and Construction, Vol. 19 No. 1, pp. 55-75.

46. Strauss, A. and Corbin, J. (1998), Basics of Qualitative Research, 2nd ed., SAGE Publication, CA.

47. Stumpf, G. (2000), "Schedule delay analysis", Cost Engineering Journal, Vol. 42 No. 7, pp. $32-$ 43.

48. Sullivan, A. and Harris, F.C. (1986), "Delays on large construction projects", International Journal of Operations \& Production Management, Vol. 6 No. 1, pp. 25-33.

49. Sweis, G., Sweis, R., Hammad, A.A. and Shboul, A. (2008), "Delays in construction projects: the case of Jordan", International Journal of Project Management, Vol. 26 No. 6, pp. 665674.

50. Toor, S.U.R. and Ogunlana, S.O. (2008), "Problems causing delays in major construction projects in Thailand", Construction Management and Economics, Vol. 26 No. 4, pp. 395-408.

51. Trauner, T.J. (2009), Construction Delays, 2nd ed., Elsevier Butherworth-Heinemann, Burlington.

52. Tumi, S.A.H., Omran, A. and Pakir, A.H.K. (2009), "Causes of delay in construction industry in Libya", The International Conference on Economics and Administration, pp. 265-272.

53. UK National Audit Office (2001), Modernising Construction, National Audit Office, London.

54. UK National Audit Office (2009), Performance of PFI Construction, National Audit Office, London.

55. UK National Audit Office (2010), PFI in Housing, National Audit Office, London.

56. Wolstenholme, A. (2009), "Never waste a good crisis: a review of rethink construction and thoughts for our future", Construction Excellence, London.

57. Yin, R.K. (2009), Case Study Research Design and Methods, 4th ed., Sage Publication Inc., Thousand Oaks, CA.

Further reading

1. Association of Researchers in Construction Management, available at: www.arcom.ac.uk/search.php (accessed 17 October 2013).

2. Collins, J. and Hussey, R. (2009), Business Research: A Practical Guide for Undergraduate and Postgraduate Students, 3rd ed., Palgrave Macmillan, Hampshire. 